\title{
Analisis Kelayakan Sistem Informasi Akademik Universitas Menggunakan PIECES dan TELOS
}

\author{
http://dx.doi.org/10.28932/jutisi.v7i2.3612
}

Riwayat Artikel

Received: 11 Mei 2021 | Final Revision: 16 Juni 2021 | Accepted: 6 Juli 2021

\author{
Merryana Lestari ${ }^{\otimes * 1}$, Endang Haryani ${ }^{\# 2}$, Teguh Wahyono ${ }^{\# 3}$ \\ Magister Sistem Informasi, Fakultas Teknologi Informasi, Universita Kristen Satya Wacana \\ Jalan Dr. O. Notohamidjojo No. 1 - 10, Blotongan, Salatiga - 50715, Jawa Tengah, Indonesia \\ 1972020011@student.uksw. edu \\ ${ }^{2}$ endang_hry@uksw.edu \\ 3teguh. wahyonoduksw.edu
}

\begin{abstract}
In line with the development of Information Technology (IT), it is appropriate for an educational institution to utilize Information Systems (IS) as an infrastructure that supports the academic service process. One of the universities in Central Java that has implemented IS, namely the Academic Information System. The Academic IS has been operating for 17 years since 2004. Therefore, the academic SI should be evaluated to determine its eligibility as an application. This study is a comparative analysis that has employed approaches of TELOS (Technical, Economic, Legal, Operations, Schedule) and PIECES (Performance, Information, Efficiency, Control and Security, Economics, Service), based on the WebQual dimensions. The aim is to assess the feasibility study of Academic IS, applying three approaches according to the user's perspective.
\end{abstract}

Keywords—Academic Information System; Feasibility Study; PIECES; TELOS; University.

\section{Pendahuluan}

Perkembangan Teknologi Informasi (TI) mendorong institusi pendidikan khususnya Perguruan Tinggi menerapkan Sistem Informasi (SI) yang terintegrasi pada setiap unit kerjanya untuk mendukung aktivitas utama yaitu layanan Akademik. Perguruan Tinggi adalah sebuah lembaga yang memiliki proses bisnis di bidang akademik yang mempunyai ciri khas yang spesifik sesuai dengan proses bisnis yang dijalankan. Dengan demikian bentuk SI yang dibutuhkan oleh perguruan tinggi juga harus memiliki karakteristik khusus sesuai dengan sifat dari kegiatan akademik tersebut. Tetapi saat ini masih banyak universitas di Indonesia yang belum mempunyai model atau kerangka khusus pada saat membangun SI Akademik [1]. Salah satu universitas yang berada di Jawa Tengah yang menggunakan SI Akademik sebagai sebuah sarana dan prasarana dalam menyediakan layanan kepada para mahasiswa, dosen, pegawai, dan pejabat struktural dalam unit kerjanya guna melancarkan proses pelayanan administrasi Akademik secara terintegrasi. Oleh karena itu, SI Akademik dinilai menjadi sebuah solusi bagi layanan akademik di perguruan tinggi.

Proses pengembangan SI Akademik dilakukan secara mandiri oleh universitas melalui sebuah unit yaitu Biro Teknologi dan Sistem Informasi (BTSI) sejak tahun 2003. Proses pengembangan SI Akademik seharusnya perlu memperhatikan pentingnya studi kelayakan dari suatu SI. Studi kajian kelayakan merupakan tahap yang paling penting di dalam fase pengembangan perangkat lunak (software development), karena di dalamnya melibatkan berbagai aspek dari sistem baru yang direkomendasikan, antara lain: menentukan bagian mana saja yang akan terlibat dan menggunakan serta memperhitungkan berbagai kendala yang dihadapi dengan adanya implementasi sistem yang baru. Dalam proses perkembangannya, SI Akademik menjadi inti dari administrasi layanan akademik di perguruan tinggi. Beberapa layanan SI Akademik diantaranya yaitu: proses registrasi matakuliah, pelaporan hasil studi mahasiswa dan transkrip nilai mahasiswa, administrasi keuangan, penjadwalan matakuliah setiap semester, dan presensi perkuliahan. Dengan berkembangnya universitas, baik dari sisi program maupun aktivitasnya, SI Akademik tersebut tentu juga perlu diperbaiki. Oleh karena itu, SI Akademik yang sudah dioperasikan selama 17 tahun sampai saat ini, sehingga perlu dievaluasi dan dinilai kembali untuk mengetahui apakah sistem tersebut masih layak dengan peran fungsionalitas dan sesuai dengan kebutuhannya dalam menunjang layanan akademik di perguruan tinggi. Pengkajian kelayakan SI Akademik perguruan tinggi dilakukan dengan menggunakan faktor kelayakan framework TELOS dan PIECES.

Beberapa penelitian terkait dengan topik penelitian ini pernah dilakukan, antara lain yaitu: penelitian sebelumnya yang pernah dilakukan oleh Kurniawan, dkk., pada tahun 2020 yang berjudul: “Analisa Proyek Sistem Informasi Vehicle Security 
Menggunakan Metode Analisis SWOT dan TELOS". Penelitian tersebut dilakukan dengan tujuan untuk mengetahui hasil analisa proyek sistem informasi berbasis Internet of Things (IoT) yaitu Vehicle Security dengan menggunakan metode teknik analisa SWOT dan uji kelayakan TELOS. Hasil yang diperoleh berdasarkan penelitian tersebut yaitu bahwa hasil Analisa SWOT dinilai positif meskipun terdapat beberapa hal yang perlu dibenahi untuk ke depannya. [2].

Penelitian kedua yang dilakukan oleh Asbar, dkk., pada tahun 2017 dengan judul: "Analisa dalam Mengukur Kualitas Pelayanan Terhadap Kepuasan Konsumen Menggunakan Metode PIECES” bertujuan untuk mengetahui pengukuran kepuasan pelanggan pada perusahaan. Hasil penelitian ini dapat menggambarkan perusahaan untuk melihat nilai dari para karyawannya berdasarkan indikator kinerja, indikator informasi, indikator ekonomi, pengendalian indikator, efisiensi indikator dan pelayanan indikator [3].

Penelitian ketiga yang berkaitan dengan penelitian ini yaitu tentang analisis kualitas layanan website memakai pendekatan WebQual oleh Arifin, dkk., pada tahun 2015, yang berjudul: “Analisis Kualitas Layanan Website Universitas Hasanuddin Menggunakan Metode WebQual 4.0 Modifikasi” mencoba melakukan analisis terhadap mutu layanan website Universitas Hasanuddin untuk tujuan dalam rangka melihat perbedaan antara sudut pandang aktual dan harapan ideal pengguna website, dalam hal ini mahasiswa UNHAS, yang diukur menggunakan metode WebQual 4.0 yang adalah suatu cara pengukuran mutu website berdasarkan sudut pandang pengguna. Hasil penelitian menunjukkan informasi yaitu terdapat perbedaan (gap) antara sudut pandang aktual dan harapan ideal dari para mahasiswa pada masing - masing dimensi kualitas layanan website [4].

Penelitian keempat dengan judul: "Evaluasi Usabilitas Layanan Sistem Informasi Akademik Menggunakan Metode WebQual (Studi Kasus: SIAKAD STKIP PGRI Pacitan)" pernah dilakukan oleh Dimuksa, dkk., dalam tahun 2020 dengan tujuan guna melakukan penilaian terhadap tingkat penggunaan layanan Sistem Informasi Akademik (SIAKAD) STKIP PGRI Pacitan memakai pendekatan WebQual 4.0. Tujuan penelitian tersebut adalah guna melihat sejauh mana dampak mutu layanan SIAKAD terhadap tingkat kepuasan pengguna. Penelitian tersebut memakai regresi linier berganda, sedangkan guna melihat gap (kesenjangan) antara ekspektasi pengguna dan kinerja sistem dipakai pendekatan Importance Performance Analysis. Oleh karena itu, dibutuhkan adanya perbaikan supaya kinerja dari SIAKAD dapat memenuhi ekspektasi dari pengguna, terutama untuk variabel Interaction karena mempunyai nilai kesenjangan terbesar yaitu -0,89 [5].

Penelitian kelima dengan judul: "Higher Education Internal Academic Quality Audit Information System" yang dilakukan oleh Sudianto, dkk. tahun 2020 membahas bagaimana Universitas Kristen Indonesia Paulus (UKI Paulus) telah memulai sistem penjaminan mutu perguruan tinggi dengan menetapkan standar, kebijakan dan kualitas dokumen. Namun belum didukung oleh sistem informasi yang membuat proses sosialisasi standar, kebijakan dan dokumen mutu menjadi tidak efektif dan menyebabkan terbatasnya akses bagi siapa saja yang membutuhkan informasi tersebut. Selain itu, selama pelaksanaan monitoring dan evaluasi, audit mutu juga tidak efisien dan menjadi penghambat penerapan sistem penjaminan mutu. Oleh karena itu, sistem informasi berbasis data Audit Mutu Akademik Internal (AMAI) dikembangkan dengan menggunakan Unified Modeling Language sebagai bagian dari teknologi informasi dan komunikasi. Penilaian AMAI UKI Paulus dilakukan oleh auditor ke setiap departemen dengan melihat form yang diaudit kemudian menghitung skor masingmasing rubrik untuk mendapatkan nilai standar dan perspektif. Sistem AMAI memberikan laporan penilaian kualitas akademik dari masing-masing jurusan kepada pimpinan unit pelaksana terkait. Kehadiran sistem ini telah membantu penerapan sistem penjaminan mutu bagi perguruan tinggi dalam rangka meningkatkan kualitas institusinya. Pengembangan sistem informasi berbasis data, AMAI, menggunakan lima tahapan paradigma System Development Life Cycle (SDLC): (1) identifikasi kebutuhan sistem; (2) analisis dan pemodelan sistem; (3) membuat sistem; (4) penilaian dan perbaikan sistem; (5) pelaksanaan [6].

Berdasarkan beberapa hasil penelitian sebelumnya, maka penelitian ini akan melakukan perbandingan hasil analisis kelayakan penggunaan SI Akademik menggunakan 2 (dua) pendekatan yaitu pendekatan PIECES guna mengetahui bagaimana analisa sistem terhadap 6 aspek dalam pengukuran kualitas pelayanan atau service terhadap kepuasan pengguna serta kinerja sistem informasi tersebut, dan pendekatan TELOS dengan 5 analisa aspek untuk mengetahui apakah diperlukannya sebuah pengembangan sistem informasi akademik yang baru, analisa tersebut akan dipetakan berdasarkan dimensi WebQual yang diperoleh dari hasil analisis kuesioner berdasarkan perspektif kepuasan pengguna sehingga akan didapatkan metode apa yang tepat digunakan untuk melihat kelayakan pengguna SI Akademik di perguruan tinggi.

Sistem Informasi Akademik (SIA) merupakan salah satu bentuk teknologi informasi berupa layanan perangkat lunak dalam proses pendidikan termasuk informasi akademik. Untuk mendapatkan layanan SIA yang baik, diperlukan tata kelola yang baik, termasuk dukungan TI, layanan bagi pengguna TI serta kesinambungan perawatan [7].

Metode WebQual dipakai sebagai kriteria perbandingan terhadap hasil penilaian kepuasan pengguna terhadap SI Akademik. WebQual merupakan suatu pendekatan yang dipakai guna mengukur kualitas website berdasar respon pengguna terakhir. WebQual terdiri dari 3 (tiga) dimensi yaitu dimensi Kualitas Penggunaan (Usability Quality), dimensi Kualitas Informasi (Information Quality), dan dimensi Kualitas Interaksi (Interaction Quality). Perkembangan Dimensi WebQual 4.0 merupakan modifikasi yang terdiri dari: Usability, Information, Service Interaction, dan User Interface [8]. Penilaian website pada dimensi kualitas penggunaan antara lain kemudahan untuk ditelusuri, mudah untuk dipakai, sangat menarik, 
mudah untuk dipelajari, selalu menampilkan hal yang menyenangkan. Pada dimensi kualitas informasi website dinilai dengan kriteria antara lain tentang informasi yang dipercaya, akurat, informasi terkini, informasi yang dapat dipahami. Sedangkan, pada dimensi kualitas interaksi website dinilai dari rasa aman bertransaksi, reputasi yang baik, mudahnya komunikasi, memiliki kepercayaan menyimpan informasi, dan memberi keyakinan untuk janji yang diberikan akan ditepati [9]. Dimensi WebQual, dipakai pada penelitian ini sebagai pengarah dalam merumuskan pertanyaan - pertanyaan kuesioner yang akan dijawab oleh responden.

Metode PIECES mempunyai tujuan untuk mengidentifikasi masalah, harus dilakukan analisis terhadap kineja, informasi, ekonomi, keamanan, efisiensi, dan pelayanan. Metode ini dikenal dengan nama PIECES analysis (Performance, Information, Economic, Control, Efficiency, Service). Dengan memakai metode analisis PIECES ini akan diperoleh beberapa temuan masalah dan akhirnya dapat ditentukan masalah utamanya [10]. Untuk menganalisis sebuah sistem informasi memakai PIECES harus ditekankan 6 aspek penilaian, aspek pertama adalah performance untuk melihat seberapa andalkan sistem informasi dalam kinerjanya sesuai dengan tujuan dikembangkannya sistem informasi, aspek kedua adalah information untuk mengetahui seberapa akurat kualitas informasi dari sistem tersebut melalui data input sampai ke output, ketiga adalah economic yang menganalisa bagaimana biaya yang digunakan dalam operasional sistem maupun pertambahan nilai manfaatnya selama sistem digunakan, keempat adalah control yaitu pengukuran sistem informasi terhadap pengendalian dalam menemukan kesalahan maupun kecurangan yang terjadi, kelima adalah eficiency yang mengukur tentang efisiensi sistem informasi tersebut selama berproses, dan terakhir adalah service yang menilai pelayanan dalam peningkatan kualitas sistem secara keseluruhan terhadap kepuasan pengguna.

Pendekatan selanjutnya adalah metode TELOS bertujuan untuk menilai pengujian kelayakan terhadap sistem baru yang akan dikembangkan. Metode TELOS berdasarkan 5 (lima) buah aspek yaitu Technical, Economic, Legal, Operations dan Schedule. Aspek teknis (Technical) digunakan untuk menguji penerapan teknologi yang sudah ada atau teknologi baru jika diperlukan, aspek ekonomi (Economic) meneliti efek dari ekonomi atau ketersediaan dana untuk menyelesaikan proyek, aspek hukum (Legal) menguji faktor legalitas jika sebuah proyek melanggar hukum, aspek operasional (Operations) menilai faktor operasional untuk mengetahui kelayakan dari penggunaan sistem dan aspek penjadwalan (Schedule) diperhitungkan untuk menguji ketepatan waktu dalam penyelesaian proyek. Metodologi TELOS memberikan tinjauan yang komprehensif dan holistik untuk membuat studi kelayakan secara umum. Lima aspek studi kelayakan, jika dilakukan secara objektif, dapat memberikan informasi yang cukup kepada pengambil keputusan untuk menugaskan audit sistem informasi, dan juga berkontribusi dalam perencanaan audit yang lebih baik [11].

\section{METODE}

Metodologi penelitian yang digunakan adalah dengan pendekatan deskriptif kualitatif. Metode yang digunakan untuk menilai dan menguji kelayakan sistem dalam penelitian ini menggunakan 2 (dua) metode pendekatan, yaitu analisa sistem informasi yang diteliti dengan menggunakan metode PIECES dan membandingkannya dengan hasil kuesioner menggunakan pendekatan dimensi WebQual terhadap kepuasan pengguna langsung sistem, kemudian digunakan metode TELOS untuk menilai apakah diperlukannya sebuah sistem informasi yang baru dan apakah layak suatu sistem informasi yang baru tersebut dikembangkan. Gambar 1 menunjukkan bagaimana tahapan penelitian yang dilakukan.

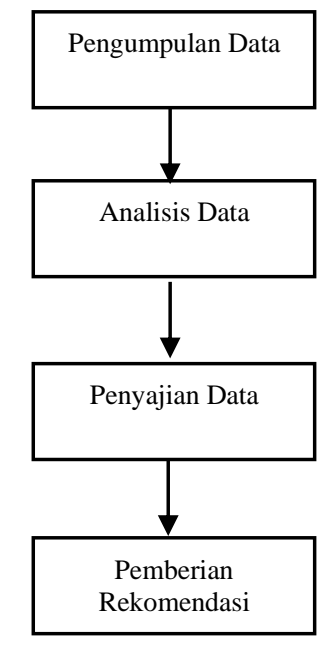

Gambar 1. Tahapan Penelitian 
Tahapan penelitian yang dilakukan seperti pada Gambar 1 yaitu dimulai dengan pengumpulan data kepada pihak BTSI untuk memperoleh informasi mengenai pengembangan dan operasional SI Akademik. Tahap selanjutnya adalah proses analisis data dengan membandingkan hasil kajian kelayakan SI Akademik menggunakan metode TELOS dan PIECES berdasarkan WebQual. Kemudian, hasil perbandingan disajikan dalam bentuk informasi dari berbagai kriteria di dalam metode TELOS dan PIECES. Sehingga pada akhirnya dapat diberikan rekomendasi dan kesimpulan mengenai kelayakan SI Akademik.

Penelitian ini membagi tahap pengumpulan data menjadi 3 (tiga) yaitu tahap wawancara, tahap kuesioner dan tahap studi pustaka. Dalam tahapan wawancara dilakukan tanya jawab secara langsung dengan Kepala Bagian Sistem Informasi sebagai developer SI Akademik mengenai dokumentasi sistem dan informasi perancangan dan pengembangan website SI Akademik dengan lebih detail. Dalam tahapan kuesioner peneliti memberikan kuesioner berupa 10 (sepuluh) pertanyaan kepada pengguna internal dan eksternal yang meliputi dosen, mahasiswa dan staff admin untuk mengetahui bagaimana respon kepuasan mereka mengenai SI Akademik tersebut dari segi perspektif kepuasan pengguna berdasarkan penilaian 3 aspek dalam WebQual yang dinilai dalam skala Likert dan sebelumnya pertanyaan-pertanyaan tersebut sudah diuji validitas dan reabilitasnya, SI Akademik itu sendiri yang bertujuan untuk mendapatkan gambaran tentang pengukuran kinerja Sistem Informasi Akademik agar dapat melakukan analisis secara tepat [12].

Penilaian keseluruhan dari faktor kelayakan TELOS didapatkan dengan teknik mencari nilai rata - rata dari keseluruhan faktor kelayakan TELOS. Semakin rendah nilai rata - ratanya, maka semakin tinggi juga risiko pengembangan dan penerapan sistem. Sebaliknya, semakin tinggi nilai rata - ratanya, maka semakin rendah risikonya. Pada uji kelayakan TELOS dibuat serangkaian kriteria yang menjadi tolok ukur standar penilaian masing - masing faktor, seperti pada Tabel 1.

TABEL 1

KRITERIA TOLOK UKUR PENILAIAN FAKTOR TELOS

\begin{tabular}{clcc}
\hline \multirow{2}{*}{ Faktor } & \multicolumn{1}{c}{ Kriteria Tolok Ukur } & Skor Nilai \\
\cline { 3 - 4 } Technical & $\begin{array}{l}\text { Menunjukkan apakah sistem yang diusulkan dapat dikembangkan dan diterapkan } \\
\text { dengan menggunakan teknologi yang ada atau jika membutuhkan teknologi baru. }\end{array}$ & $\begin{array}{c}\text { Tidak } \\
\text { Ada }\end{array}$ \\
\cline { 2 - 3 } Economic & $\begin{array}{l}\text { Menunjukkan komitmen pendanaan dari organisasi, apakah dana yang memadai } \\
\text { tersedia untuk mendukung biaya dari sistem yang diusulkan. }\end{array}$ & $6-8$ \\
& $\begin{array}{l}\text { Menunjukkan apakah ada konflik antara sistem yang sedang dipertimbangkan } \\
\text { terhadap pelanggaran hukum dan kemampuan perusahaan untuk menunaikan } \\
\text { kewajibannya. } \\
\text { Menunjukkan apakah prosedur dan keterampilan personalia yang ada cukup untuk }\end{array}$ & $9-10$ & $5-8$ \\
Operations & $\begin{array}{l}\text { mengoperasikan sistem yang diusulkan atau apakah prosedur dan keterampilan } \\
\text { tambahan akan diberikan. }\end{array}$ & $8-10$ & $5-7$ \\
Schedule & $\begin{array}{l}\text { Adanya penjadwalan perancangan dan pengembangan sistem dan sistem yang } \\
\text { diusulkan harus berlaku dalam suatu kerangka waktu yang logis. }\end{array}$ & $8-10$ & $5-7$ \\
\hline
\end{tabular}

Rumus 1 digunakan untuk menghitung nilai TELOS.

Nilai TELOS = Nilai Technical + Nilai Economic + Nilai Legal + Nilai Operational + Nilai Schedule (1)

\section{HASIL DAN PEMBAHASAN}

SI Akademik merupakan sarana dan prasarana dalam memberikan layanan akademik di perguruan tinggi. Sistem Informasi Akademik digunakan oleh mahasiswa, dosen, staff, dan struktural dalam unit kerjanya guna melakukan proses pelayanan administrasi Akademik secara terintegrasi. Dalam penelitian ini peneliti melibatkan data kuesioner dari 227 orang responden yang terdiri dari 17 orang dosen, 204 orang mahasiswa dan 6 orang staff pengguna SI Akademik dalam melakukan uji analisa terhadap kualitas website SI Akademik berdasarkan dimensi WebQual. Hasil kuesioner dalam melakukan teknik pengukuran kualitas website berdasarkan persepsi pengguna akhir seperti pada Gambar 2. 


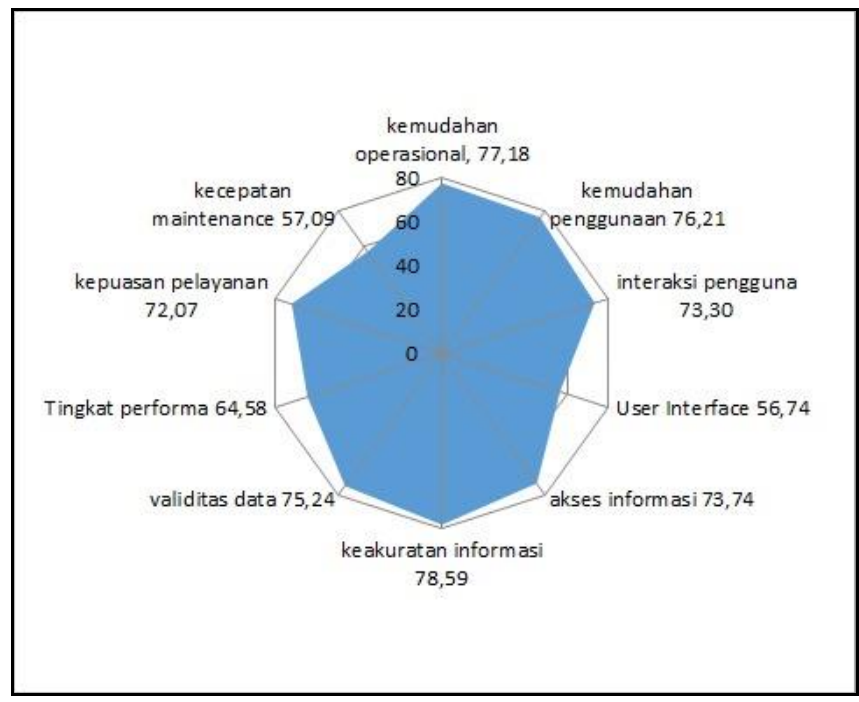

Gambar 2. Visualisasi Data Kuesioner

SI Akademik ini dibangun dengan menggunakan teknologi web 2.0 karena menggunakan layanan platform website dengan data sebagai pengendali utama. Bahasa pemrograman yang digunakan adalah ASP.Net dengan SQL Server sebagai Database Management System-nya dan menggunakan rancangan skema database Entity Relationship Diagram (ERD) yang sangat komplek.

Pada kebutuhan implementasi hardware SI Akademik menggunakan 2 (dua) buah server yaitu server utama dan server backup dengan kriteria menggunakan sistem operasi Windows, dan hardware yang memenuhi standar sebuah server. Lisensi perangkat keras dan perangkat lunak juga menjadi faktor dominan yang menjadi tolak ukur tentang legalitas hukum dari proyek yang dibuat, dalam hal ini, software dan hardware yang digunakan dalam pengembangan dan operasional SI Akademik semuanya mempunyai lisensi yang sah.

Keamanan sistem juga sangat diperhitungkan dalam website SI Akademik, dengan menggunakan 3 layer keamanan yaitu Application layer, Business layer, dan Database layer maka, integritas data dapat terjaga. Sayangnya, developer SI Akademik tidak memiliki tim dalam pengembangan sistem informasi tersebut, proses perancangan dan pengembangan SI Akademik tersebut dilakukan oleh 1 (satu) orang saja sehingga dinilai pengembangan SIA sangat beresiko.

Infrastruktur teknologi yang menjadi tolak ukur selanjutnya adalah akses internet yang stabil. Akses internet di perguruan tinggi sudah memenuhi kebutuhan penggunanya, karena sudah tersedianya jaringan WiFi di semua lokasi kampus. Sedangkan, untuk akses internet di luar kampus sudah didukung oleh banyak provider, hanya saja akses internet di Indonesia masih belum mumpuni sehingga website SI Akademik tidak dapat diakses dengan baik ketika pengguna berada pada area yang tidak terjangkau internet dengan baik.

Dalam kegunaan SI Akademik ini sendiri, merupakan salah satu urat nadi dalam kegiatan akademik di perguruan tinggi. SI Akademik tersebut dipandang sebagai salah satu sistem yang mempunyai peran manfaat penting bagi kelangsungan layanan akademik karena terintegrasi dengan unit-unit kerja yang penting. Namun terdapat kekurangan yang dipandang akan menimbulkan masalah dikemudian hari, yaitu belum terdapatnya penjadwalan rutin yang jelas mengenai update dan maintenance dari SI Akademik pada saat ini.

Berdasarkan deskripsi data yang diperoleh, maka melalui pendekatan dengan metode PIECES dan TELOS menurut dimensi WebQual berdasarkan perspektif pengguna dapat ditabulasi ke dalam perbandingan seperti pada Tabel 2 berikut:

TABEL 2

Perbandingan Analisis Menurut Pendekatan PIECES dan TELOS Berdasarkan Dimensi WebQual Menurut Perspektif PengGuna

\begin{tabular}{|c|c|c|}
\hline \multicolumn{3}{|c|}{ Pendekatan/Metode } \\
\hline WebQual & PIECES & TELOS \\
\hline $\begin{array}{l}\text { Usability Quality } \\
\text { - Tingkat kemudahan dalam } \\
\text { mengoperasionalkan website SI } \\
\text { Akademik sudah termasuk baik } \\
\text { menurut } 44,49 \% \text { responden dan } \\
\end{array}$ & $\begin{array}{l}\text { Performance } \\
\text { Analisis Performance menguji } \\
\text { apakah website SI Akademik dapat } \\
\text { memberikan respon yang cepat pada } \\
\text { saat pengguna melakukan aktivitas }\end{array}$ & $\begin{array}{ll}\text { 1. } & \text { Technical } \\
\text { Teknologi yang digunakan dalam } \\
\text { proyek perancangan dan } \\
\text { pengembangan SI Akademik } \\
\text { menjadi acuan utama sebagai faktor }\end{array}$ \\
\hline
\end{tabular}


termasuk cukup baik menurut $26,43 \%$ responden.

- Tingkat kemudahan penggunaan dan navigasi website SI Akademik sudah termasuk baik menurut $51,54 \%$ responden dan termasuk cukup baik menurut $23,79 \%$ responden.

- Tingkat ketertarikan terhadap tampilan User Interface website SI Akademik termasuk cukup baik menurut $33,48 \%$ responden.

2. Information Quality

- Tingkat validitas data dalam SI

Akademik dipandang baik dari

$50,66 \%$ responden dan $31,28 \%$

dipandang cukup baik oleh

responden.

- Tingkat kemudahan dalam akses informasi pada SI Akademik termasuk baik menurut $46,26 \%$ responden dan termasuk cukup baik menurut $29,07 \%$ responden.

- Tingkat keakuratan dan

kepercayaan terhadap informasi yang didapatkan sudah termasuk baik menurut $57,71 \%$ responden dan cukup baik menurut $22,03 \%$ responden.

3. Interaction Quality

- Tingkat kejelasan interaksi pengguna terhadap SI Akademik sudah termasuk baik menurut $41,41 \%$ responden dan termasuk cukup baik menurut $29,96 \%$ responden.

- Tingkat kepuasan pelayanan yang diberikan oleh BTSI khususnya dalam operasional SI Akademik adalah termasuk baik menurut $45,37 \%$ responden dan termasuk cukup baik menurut $39,21 \%$ responden.

- Tingkat performa SI Akademik termasuk cukup baik menurut $42,29 \%$ responden.

- Tingkat kecepatan maintenance dalam menyelesaikan error sistem dalam SI Akademik termasuk cukup baik menurut $48,46 \%$ responden. di dalam website. Hasil analisis

Performance menunjukkan bahwa

kualitas penggunaan sudah termasuk baik yang dibuktikan melalui pengguna yang dapat menggunakan menu dan navigasi yang ada di dalam website dengan mudah sehingga mempercepat proses layanan Akademik.

\section{Information}

Analisis Information menguji apakah setiap informasi yang ada di dalam website SI Akademik menghasilkan informasi yang sesuai dengan kebutuhan pengguna. Hasil analisis Information menunjukkan bahwa setiap informasi yang ada di dalam website SI Akademik telah dipandang baik serta memberikan manfaat kepada para pengguna sesuai dengan kebutuhan masingmasing pengguna baik mahasiswa, dosen, staff, maupun struktural.

\section{Efficiency}

Analisis Efficiency menguji apakah output yang dihasilkan oleh website SI Akademik dapat dimanfaatkan sebaik-baiknya oleh para stakeholder. Hasil analisis Efficiency menunjukkan bahwa website SI Akademik sudah termasuk baik dalam memanfaatkan data yang ada di dalam sistem untuk digunakan sebagai dasar pengambilan keputusan manajerial.

\section{Control and Security}

Analisis Control and Security menguji apakah website SI Akademik memiliki tingkat keamanan yang baik. Hasil analisis Control and Security menunjukkan bahwa website SI Akademik sudah tergolong baik dalam menjamin keamanan data dan informasi yang ada di dalam sistem karena memiliki pembagian hak akses pengguna sesuai dengan fungsinya masingmasing.

\section{Economy}

Analisis Economy menguji apakah website SI Akademik dapat memberikan keuntungan dan menekan biaya operasional. Hasil analisis Economy menunjukkan bahwa dengan adanya website SI Akademik, maka perguruan tinggi dapat merasakan manfaat yaitu dengan efisiensi biaya operasional kelayakan teknis yang dapat menentukan apakah produk yang dihasilkan dari proyek tersebut memiliki manfaat sesuai dengan kebutuhan penggunanya atau tidak. Website dengan teknologi 2.0 sudah termasuk usang dalam fungsionalitasnya, dan sebaiknya perlu ditinjau ulang apakah perlu pengembangan sistem yang baru dengan teknologi yang baru atau dilakukan adaptasi mengikuti perkembangan teknologi. Berdasarkan nilai untuk faktor kelayakan teknis SI Akademik adalah 9,5.

2. Economic

Kelayakan ekonomi berfokus pada apakah sistem harus dibangun dengan didalamnya terdapat analisis biaya dan manfaat. Faktor ekonomi menjadi salah satu faktor yang gunakan sebagai analisa uji kelayakan proyek sistem informasi. Dalam analisis kelayakan ekonomi, SI Akademik dipandang sebagai salah satu sistem yang mempunyai peran manfaat penting bagi kelangsungan layanan akademik karena terintegrasi dengan unit-unit kerja yang penting, maka nilai untuk faktor kelayakan ekonomi SI Akademik adalah 10.

3. Legal

Faktor legalitas atau kelayakan hukum perlu dipertimbangkan, karena apabila sebuah proyek melanggar suatu hukum tentu sangat beresiko jika dikembangkan. SI Akademik tersebut dikembangkan dengan tidak melanggar hukum, maka nilai untuk faktor kelayakan hukum SI Akademik adalah 10.

4. Operations

Menilai kelayakan operasional sebuah sistem informasi dapat dilakukan dengan menilai adanya pengguna yang terlatih dengan baik dan berdedikasi untuk menjalankan sistem. Berdasarkan belum adanya inisiasi developer dalam pengembangan ataupun adaptasi teknologi baru dalam SI Akademik tersebut, maka nilai untuk faktor kelayakan operasional SI Akademik adalah 7 .

5. Schedule Penilaian kelayakan penjadwalan 
antara lain seperti: biaya

telekomunikasi, biaya ATK, dan

biaya gaji pegawai dapat ditekan

dibandingkan sebelum

menggunakan sistem.

6. Service

Analisis Service menguji apakah website SI Akademik menyediakan layanan data atau informasi bagi para penggunanya. Hasil analisis Service menunjukkan bahwa data dan informasi yang disediakan oleh website SI Akademik sudah cukup baik dan dapat memberikan kemudahan bagi para pengguna untuk mengakses secara cepat dan mudah walaupun dipandang perlunya perbaikan atas peningkatan kualitas pelayanan.

\author{
dapat diukur berdasarkan estimasi \\ waktu. Dalam perancangan SI \\ Akademik, tidak terdapat schedule \\ yang jelas dan tidak dijadwalkan \\ secara rutin, begitu pula mengenai \\ pengembangan SI Akademik yang \\ baru juga belum direncanakan. \\ Berdasarkan kriteria penilaian \\ TELOS, maka nilai untuk faktor \\ kelayakan penjadwalan SI \\ Akademik adalah 5.
}

Hasil penelitian berdasarkan pendekatan PIECES (Performance, Information, Efficiency, Control and Security, Economy, and Service) pada aspek Efficiency menunjukkan bahwa output yang dihasilkan oleh website SI Akademik dapat dimanfaatkan sebaik-baiknya oleh para stakeholder. Hasil analisis Efficiency yang lain menunjukkan bahwa website SI Akademik memanfaatkan data yang ada di dalam sistem untuk digunakan sebagai dasar pengambilan keputusan manajerial dengan persentase sebesar $50,66 \%$ responden menyatakan baik.

Pada aspek Economy menunjukkan bahwa website SI Akademik dapat memberikan keuntungan dan menekan biaya operasional. Hasil analisis Economy menunjukkan bahwa dengan adanya website SI Akademik, maka perguruan tinggi dapat merasakan manfaat yaitu biaya operasional antara lain seperti: biaya telekomunikasi, biaya ATK, dan biaya gaji pegawai dapat ditekan dibandingkan sebelum menggunakan sistem dengan persentase sebesar $45.37 \%$ responden menyatakan baik.

Pada aspek Performance menunjukkan bahwa website SI Akademik dapat memberikan respon yang cepat pada saat pengguna melakukan aktivitas di dalam website. Hasil analisis Performance menunjukkan bahwa pengguna dapat menggunakan menu dan navigasi yang ada di dalam website dengan mudah sehingga mempercepat proses layanan akademik dengan persentase sebesar $51.54 \%$ responden menyatakan baik.

Pada aspek Service menunjukkan bahwa website SI Akademik menyediakan layanan data atau informasi bagi para penggunanya. Hasil analisis Service menunjukkan bahwa data dan informasi yang disediakan oleh website SI Akademik dapat memberikan kemudahan bagi para pengguna untuk mengakses secara cepat dan mudah dengan persentase $48.46 \%$ responden menyatakan cukup baik.

Pada aspek Information menunjukkan bahwa setiap informasi yang ada di dalam website SI Akademik menghasilkan informasi yang sesuai dengan kebutuhan pengguna. Hasil analisis Information menunjukkan bahwa setiap informasi yang ada di dalam website SI Akademik telah memberikan manfaat kepada para pengguna sesuai dengan kebutuhan masingmasing pengguna baik mahasiswa, dosen, staff, maupun struktural dengan persentase 57,71\% responden menyatakan baik.

Pada aspek Control and Security menunjukkan bahwa website SI Akademik memiliki tingkat keamanan yang baik. Hasil analisis Control and Security menunjukkan bahwa website SI Akademik dapat menjamin keamanan data yang ada di dalam sistem karena memiliki pembagian hak akses pengguna sesuai dengan fungsinya masing-masing yaitu mahasiswa, dosen, staff, dan struktural dengan persentase $42,29 \%$ responden menyatakan cukup baik.

\section{SIMPULAN}

Berdasarkan hasil penelitian yang telah dilakukan, maka diperoleh bahwa kriteria penilaian faktor Kelayakan Teknis, SI Akademik yang diterapkan sudah menggunakan teknologi yang sudah ada dan telah dipakai secara umum serta diketahui oleh manajemen perguruan tinggi, sehingga nilai untuk kelayakan teknik, yaitu berkisar antara 9.5 sampai dengan 10 . Manajemen perguruan tinggi memberikan indikasi bahwa pihak manajemen mendukung SI Akademik, akan tetapi belum dapat menyediakan dana yang dibutuhkan, sehingga penilaian kelayakan ekonomi berkisar antara 5 sampai dengan 8. Selain itu juga perlu adanya sumber daya manusia yang terlatih sebagai administrator dan operator SI untuk dapat menggunakan dan mengoperasikan SI dengan baik, sehingga penilaian untuk kelayakan operasional diberikan nilai 7. Dalam penilaian faktor Kelayakan Hukum, diberikan nilai 10. Pada penilaian faktor Kelayakan Operasional dilihat bahwa keberadaan pengguna atau sumber daya yang terlatih dengan baik dan memiliki komitmen kuat untuk menjalankan SI Akademik. 
Kemudian, penilaian untuk Kelayakan Penjadwalan yang diimplementasikan tidak terlalu kompleks atau sederhana, dan merupakan sistem yang standar dan berbasis lokal, serta total waktu pengembangan diukur dengan satuan jam atau hari, sehingga estimasi waktu yang dibutuhkan dalam perancangan dan implementasi menjadi cepat dan kecil.

\section{DAFTAR PUSTAKA}

[1] Mutyarini dan Sembiring. (2006). "Arsitektur Sistem Informasi untuk Institusi Perguruan Tinggi di Indonesia". Prosiding Konferensi Nasional Teknologi Informasi dan Komunikasi untuk Indonesia, Bandung.

[2] Kurniawan, Rizky. dkk. (2020). “Analisa Proyek Sistem Informasi Vehicle Security Menggunakan Metode Analisis SWOT dan TELOS”. Journal of Information System Informatic and Computing (JISICOM) Volume 4, Nomor 2.

[3] Asbar Yuli, Mochamad Ari Saptari. (2017). “Analisis dalam Mengukur Kualitas Pelayanan Terhadap Kepuasan Konsumen Menggunakan Metode PIECES”. Jurnal Visionaer dan Strategis Volume 6, Nomor 2.

[4] Arifin, Suci Ramadhani, Nugroho, E., dan Sunarfri Hantono, B. (2020). "Analisis Kualitas Layanan Website Universitas Hasanuddin dengan Metode Webqual 4.0 Modifikasi”. Jurnal TEKNOMATIKA Volume 8, Nomor 1.

[5] Dimuksa, Wira, Kusrini, Kusrini, Fatta, dan Hanif Al., (2020). "Evaluasi Usabilitas Layanan Sistem Informasi Akademik Menggunakan Metode Webqual (Studi Kasus: SIAKAD STKIP PGRI Pacitan)". Jurnal Penelitian Pendidikan.

[6] Sudianto, L., Petrus Simon. (2020). "Higher Education Internal Academic Quality Audit Information System". International Journal of Research GRANTHAALAYAH Vol. 8, No. 1.

[7] Rahmaani, A. R., Muhammad D. F., Sumarsono. (2016). "An Audit of the Academic Information System of UIN Sunan Kalijaga”. International Journal on Informatics for Development (IJID) Vol. 5 No. 1.

[8] Hekhmatyar, O. G., Deddy S. (2017). “Measurement Satisfaction Information System Quality Service on BSI Using WebQual and CSI”. Indonesian Journal on Computer and Information Technology Vol. 2 No. 2.

[9] Widyastuti, I. T., Umar, A., dan Bawono, A. (2017). “Analisis Kinerja Perusahaan dengan Metode Balanced Scorecard". Jurnal Administrasi dan Kesekretarisan Volume 3, Nomor 1.

[10] Lukman, Ari, dkk. (2016). “Analisis Pengaruh Kualitas Website Terhadap Kepuasan Pengguna Berdasarkan Metode WebQual 4.0 Pada Website SMA N 2 Kota Mojokerto". JSIKA Volume 5, Nomor 11.

[11] Drljaca, D. P., Branko Latinovic. (2018). "Using TELOS for the Planning of the Information System Audit". IOP Conference Series Materials Science and Engineering.

[12] Syaifullah, S. dan J. Widianto. (2014). "Studi Kelayakan Sistem Informasi Akademik Berbasis Web pada Poltekes Kemenkes Riau dengan Menggunakan Metode Kelayakan TELOS”. Jurnal Sains dan Teknologi Indonesia. 